This is an author produced version of a paper published in Open house International. This paper has been peer-reviewed but does not include the final publisher proof-corrections or journal pagination.

Citation for the published paper:

Siggelsten, Simon; Nordquist, Birgitta; Olander, Stefan. (2014). Analysis of the accuracy of individual heat metering and charging. Open house International, vol. 39, issue 2, p. null

URL: http://hdl.handle.net/2043/18246

Publisher: Open House International Association

This document has been downloaded from MUEP (https://muep.mah.se) / DIVA (https://mau.diva-portal.org). 


\title{
ANALYSIS OF THE ACCURACY OF INDIVIDUAL HEAT METERING AND CHARGING.
}

\section{Simon Siggelsten, Birgitta Nordquist, Stefan Olander}

\begin{abstract}
Individual metering and charging (IMC) allows energy costs to be apportioned among tenants in multi-apartment buildings based on their own energy use. This can result in reduced energy use due to an increased saving behaviour by tenants, which has caught the attention of the European Parliament. In the EU-directive 2012/27/EU there is a requirement for IMC to be installed by December 31, 2016 in multi-apartment buildings.

Two techniques are mentioned in the directive for IMC: individual consumption meters and individual heat cost allocators. Either of these two techniques can be used as a method to measure the supplied energy to an apartment. Another method, not mentioned in the EU-directive, is temperature metering which means that the heating cost is instead based on measurements of the actual temperatures through sensors in certain locations in the apartment. However, some shortcomings have been identified with the aforementioned methods.

The purpose of this study is to investigate how internal heat production, solar radiation, an apartment's location within the building and local defects in the building envelope affect the accuracy of IMC. The Energy demands of three apartments in different locations within the building have been simulated in the computer program VIP-Energy. The results of energy calculations prove that the accuracy of IMC is highly questionable in some of the investigated cases. The implication of the study is that it is difficult to measure the actual heat used for an individual apartment, which obstructs accurate and fair apportioning of heating costs among individual tenants.
\end{abstract}

Keywords: EU-Directive, Energy Use, IMC, Apartment Building.

\section{Introduction}

Individual metering and charging (IMC) allows energy costs to be apportioned among tenants in multi-apartment buildings based on their own energy use. This results in reduced energy use due to an increased saving behavior by the tenants (Schou, 1982; Scott, 1991). A 10 to 20 percent reduction is realistic regarding heat use (Berndtsson, 2003; Boverket, 2006). Energy savings in the housing sector are encouraged by the European Parliament through the directive 2012/27/EU, which requires IMC of heat to the extent that it is cost-efficient and technically feasible.

Several European countries use IMC for heat but only a few countries, e.g. Denmark, prescribe it by law. The fastest growing development of IMC in recent years has occurred in China. Since the 1990s, China has gone from not using IMC at all, to both producing and installing about 2,000,000 sets of meters in 2010 alone (Wang, $2011)$. Due to the possibility to reduce energy use with IMC and the recommendation from the European Parliament, a large increase in IMC installations is expected in Europe. An argument against installation is the inaccuracy of current IMC methods.

In the EU-directive (2012/27/EU) two techniques are mentioned for IMC: individual consumption meters and individual heat cost allocators. Individual consumption meters measure the flow and temperature of water circulated in the radiator system. Heat cost allocators measure heat consumption at each radiator in an apartment. Either of these two techniques can be used as a method to measure the supplied energy to an apartment. Another method, not mentioned in the EU-directive, is temperature metering which means that the heating cost is based instead on measurements of the actual temperatures through sensors in certain locations in the apartment. This method has been chosen primary by municipally-owned real estate companies in Sweden, which are overrepresented among those few per cent who have installed IMC in Sweden (Siggelsten \& Olander, 2013).

The energy supplied to an apartment is not necessarily equal to the actual energy needed or used. Poor thermal insulation between adjacent 
apartments means that heating energy will be transmitted from one apartment to another, which makes it difficult to say which apartment used what amount of energy. Gafsi and Lefebvre (2003) have conducted a study of this problem and investigated an apartment located in the middle of a building, together with meteorological data of two weeks in December in Spain. Their results show that it is possible to gain up to about 90 per cent of the heating energy needed from the surrounding neighbors. Andersson (2001) has investigated the even more extreme location of an apartment in an existing building in Sweden, a relatively small apartment $\left(55 \mathrm{~m}^{2}\right)$ surrounded by adjacent apartments with the exception of one side only. The results show that it is possible to gain more than 95 per cent of the heating energy needed from the surrounding neighbors.

The problem with heat transmission between adjacent apartments can be partly avoided by measuring the actual temperature in the apartments instead. Measuring the actual temperature in the apartment can also pose problems, e.g. deleterious window ventilation. The problem with window ventilation is that it lowers the indoor temperature, which reduces the heating cost for the tenant at the same time as it increases the heat leading in turn to increased heating costs for the landlord.

The main purpose of this study is to investigate how the accuracy of IMC is affected by:

1. Internal heat production and solar radiation.

2. An apartment's location in the building.

3. Local defects in the building envelope.

The aim is to investigate the extent to which these parameters affect the result of IMC in combination with different family configurations.

\section{Research method}

The main tool used in this investigation is the computer program VIP-Energy (Strusoff $\AA$, 2010), which is a series of software modules covering the calculation of the energy balance for an entire building. Some of the most important factors influencing the need for energy are the outdoor climate and the building's exposure to sun and wind together with the building's ability to store heat. VIP-Energy is based on a dynamic energy equation using a physical model of the building and real weather data. The program contains calculation methods for heat storage, air infiltration, solar radiation, transmission through the ground, heat pumps etc. (ibid.).
Three apartments in different locations in two multi-apartment buildings have been simulated. Differently located apartment imply different amounts of exterior area (building envelope) and different exposures to solar radiation. The amount of exterior area together with the $U$-value will influence the extent of the heat loss due to transmission. The two different multi-apartment buildings have different $U$-values. The first multi-apartment building is an average modern building built at the beginning of the $21^{\text {st }}$ Century. The second building is representative for the construction intensive period 1961 to 1975 and represents approx. 25 per cent of today's multi-apartment buildings in Sweden (Boverket, 1999).

Internal heat production also influences a building's heat demand. For example, a larger family will contribute a higher amount of body heat and heat from electrical appliances compared to a smaller family. In order to investigate the influence of internal heat production, three different settings for internal heat production are used to represent different family sizes when making the simulations in VIP-Energy.

\section{Input data}

Three different family configurations and three different apartment locations in two different building will give 18 different cases in total. All the calculations, which are made with VIP-Energy, are based on the assumption that all apartments and stairwells are set to the same indoor temperature as in the investigated apartments. This means in practice that heat transmission will only occur through the building envelope and not between adjacent apartments or the stairwell.

The climate input data is for Malmö located in the south of Sweden. All calculations are based on a time period of six months, from $1^{\text {st }}$ of October to $31^{\text {st }}$ of March, which is the typical season when heating is needed in Malmö. The indoor temperature is set to $22.3{ }^{\circ} \mathrm{C}$, the average indoor temperature for Swedish multi-apartment buildings (Boverket, 2009).

\subsection{Two multi-apartment buildings with three apartments}

The first multi-apartment building, henceforth referred to as Building 1, is a typical modern multiapartment building with average figures for multiapartment buildings built in Sweden during the period 1996 to 2005. Building 1 has a loadbearing structure of concrete with $195 \mathrm{~mm}$ thick walls 


\begin{tabular}{|l|l|l|l|l|l|l|}
\hline & \multicolumn{4}{|l|}{ Area $\left(\mathrm{m}^{2}\right) \times \mathrm{U}$-value $\left(\mathrm{W} / \mathrm{m}^{2} \mathrm{~K}\right)$} \\
\cline { 2 - 7 } & \multicolumn{2}{|l|}{ Building 1 } & \multicolumn{2}{l|}{ Building 2 } \\
\hline Building element & $\begin{array}{l}\text { Apartment } \\
\text { A1 }\end{array}$ & $\begin{array}{l}\text { Apartment } \\
\text { B1 }\end{array}$ & $\begin{array}{l}\text { Apartment } \\
\text { C1 }\end{array}$ & $\begin{array}{l}\text { Apartment } \\
\text { A2 }\end{array}$ & $\begin{array}{l}\text { Apartment } \\
\text { B2 }\end{array}$ & $\begin{array}{l}\text { Apartment } \\
\text { C2 }\end{array}$ \\
\hline Windows & $10.4 \times 2.0$ & $9.8 \times 2.0$ & $10.4 \times 2.0$ & $10.4 \times 2.7$ & $9.8 \times 2.7$ & $10.4 \times 2.7$ \\
\hline External walls & $49.9 \times 0.20$ & $23.0 \times 0.20$ & $49.9 \times 0.20$ & $49.9 \times 0.37$ & $23.0 \times 0.37$ & $49.9 \times 0.37$ \\
\hline Roof & -- & -- & $74 \times 0.12$ & -- & -- & $74 \times 0.28$ \\
\hline
\end{tabular}

Table 7. Areas and U-values for the building envelope.

between apartments and $250 \mathrm{~mm}$ thick floor slabs with $22 \mathrm{~mm}$ wooden floors. The $U$-value for the outer walls is $0.20 \mathrm{~W} / \mathrm{m}^{2} \mathrm{~K}$ and that for the ceiling is $0.12 \mathrm{~W} / \mathrm{m}^{2} \mathrm{~K}$. The windows are triple-glazed with a U-value of $2.0 \mathrm{~W} / \mathrm{m}^{2} \mathrm{~K}$.

The second multi-apartment building, henceforth referred to as Building 2, is a typical building from the construction intensive period 1961 to 1975 in Sweden. The loadbearing structure of concrete has $150 \mathrm{~mm}$ thick walls separating apartments and $160 \mathrm{~mm}$ thick floor slabs with 22 $\mathrm{mm}$ wooden floor. The U-value for the external walls is $0.37 \mathrm{~W} / \mathrm{m}^{2} \mathrm{~K}$ and that for the roof is 0.28 $\mathrm{W} / \mathrm{m}^{2} \mathrm{~K}$. The windows are doubled-glazed with a $\mathrm{U}$-value of $2.7 \mathrm{~W} / \mathrm{m}^{2} \mathrm{~K}$. All of these U-values are representative for their time (Eriksson, 1993). All the above figures for Buildings 1 and 2 are set out in Table 1.

Neither building has been modified with heat recovery from ventilation air. The amount of ventilation in all apartments is set to 0.5 air changes per hour, in compliance with Swedish regulations.

Three apartments ( $A, B$ and $C$ ) have been simulated with different conditions, such as floor, orientation and the area abutting on adjacent apartments, see Figures 1 and 2. These conditions together with the apartments' layouts are used identically for Buildings 1 and 2. The layout is the original for the multi-apartment building which serves as a model for building 2. Apartment $A$ is located on floor two out of three at the north gable of the building. The apartment is surrounded by apartments below, above and on one side. Apartment $B$ is also located on floor two but in the middle of the building with apartments above, below and on both sides. Apartment $C$ is located on the top floor at the south gable of the building, with apartments below and on one side, resulting in the maximal area of outer walls and roof. The layouts of the apartments also affect the amount of area adjacent to other apartments, which can be seen in Figure 2. All three apartments have the same window sizes and orientation, except for the additional small windows on the gables for apartments $A$ and $C$. All three are two bedroom apartments with 74 square meters of living space. In the following, the apartments are sometimes represented by a number, e.g. apartment $A 1$. This refers to apartment $A$ in Building 1.

All apartments in this study have identical wall areas adjacent to the stairwells. The study assumes that both stairwells in the buildings have the same indoor temperature and for that reason the heat transmissions between the stairwells and the apartments are excluded, i.e. viewed as a noninfluencing parameter. Therefore all apartments have been simulated individually in VIP-Energy and not as a complete building unit.

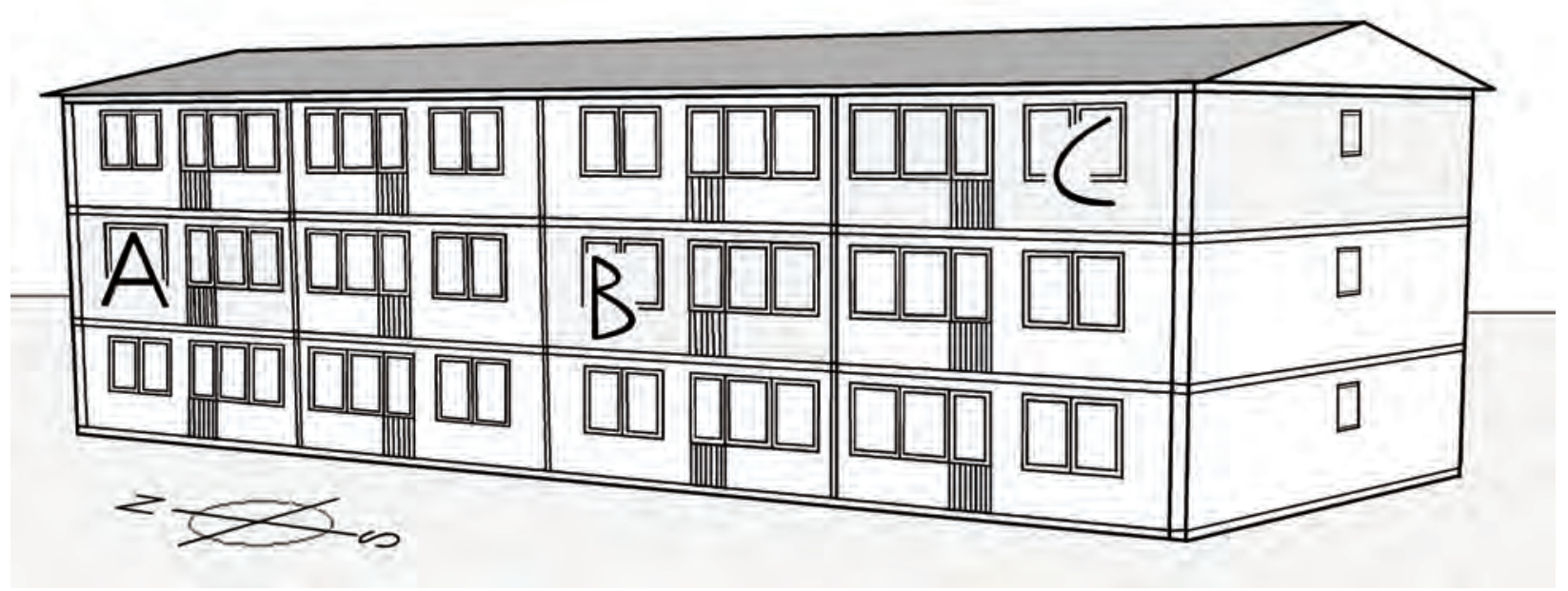

Figure 7. The locations of the three apartments in the building. 


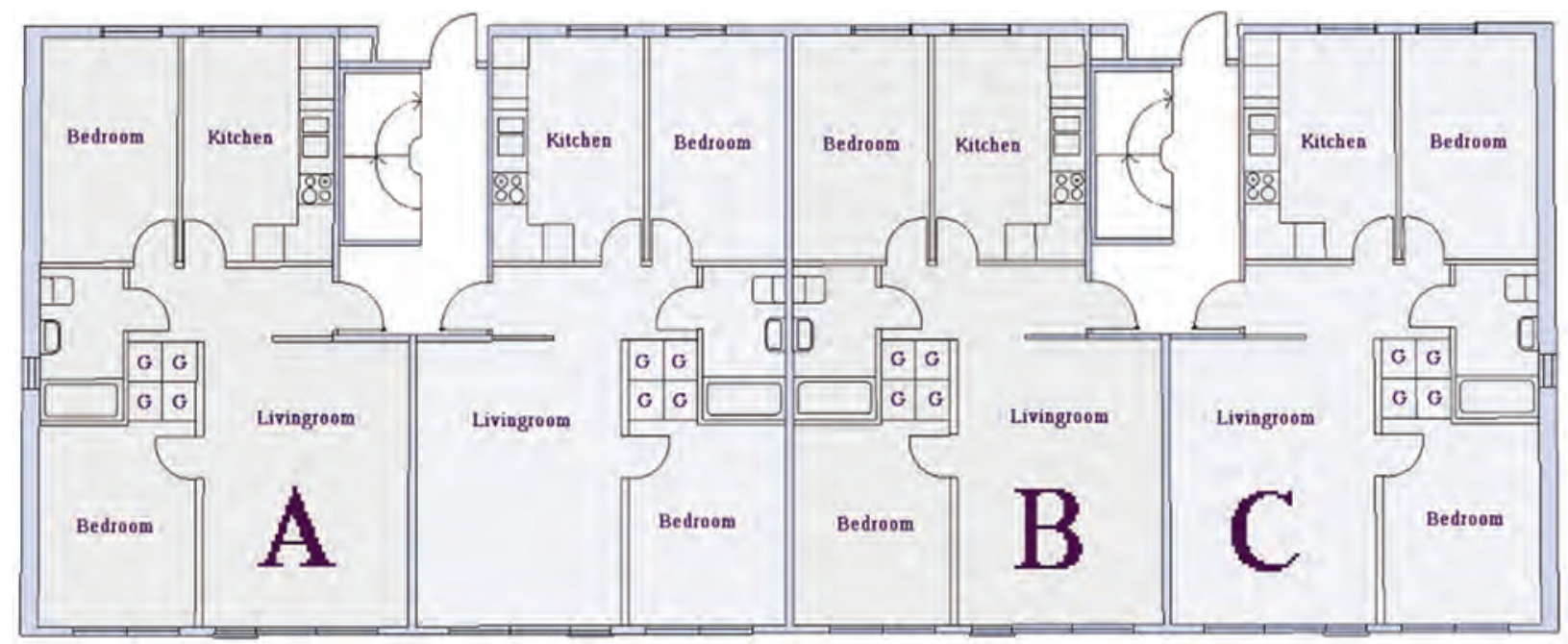

Figure 2. An illustration of the layouts.

\subsection{Family constellations}

Three different family sizes have been simulated to investigate their effect on the energy balance and, in turn, the consequences for IMC. The intention is to simulate the limit of family sizes that can be expected to be living in a two bedroom apartment with $74 \mathrm{~m}^{2}$ of living space. The body heat gain is estimated according to standard values from Fanger (1997) based on the following activities:

- Resting $46 \mathrm{~W} / \mathrm{m} 2$ (square meter body surface)

- Sitting activity $58 \mathrm{~W} / \mathrm{m} 2$

- Calm standing activity

- Normal standing activity

- Domestic work $70 \mathrm{~W} / \mathrm{m} 2$ $93 \mathrm{~W} / \mathrm{m} 2$ $116 \mathrm{~W} / \mathrm{m} 2$

The internal heat production based from lighting and electrical appliances is estimated on the basis of average household electricity usage, compiled by the Swedish Energy Agency (Energimyndigheten, 2007). The starting point for occupancy $A$ is a single adult who does not spend too much time at home. He or she is away from home 12 hours per day and watches television 1 hour per day. Occupancy B consists of two adults spending 14 hours per day at home, representing a normalsized family for this size of apartment. They watch television 1.5 hour per day. Occupancy $C$ consists of two adults and three children. Their time spent away from home varies for all family members between 4 to 10 hours per day. Their television is on for 3 hours per day. All assumptions about the three different family sizes have resulted in different values for body heat gain and internal heat production for each family, which are all presented in Table 2.

\begin{tabular}{|l|l|l}
\hline & Body heat gain $\left(\mathrm{W} / \mathrm{m}^{2}\right)$ & Internal heal production $\left(\mathrm{W} / \mathrm{m}^{2}\right)$ \\
\hline Occupancy A & 0.75 & 3.3 \\
\hline Occupancy B & 1.84 & 4.6 \\
\hline Occupancy C & 3.42 & 6.6 \\
\hline
\end{tabular}

Table 2. Body heat gain and internal heat production divided by the apartment size.

\subsection{Envelope defects}

The intention is also to study the significance of two plausible defects in the building envelope, and their influence on the result of IMC. The first defect is a $3 \mathrm{~cm}$ gap without insulation wool around the windows on the western side of the building. The second defect is a broken frame in one window, raising the U-value of the window by an estimated 0.3 $\mathrm{W} / \mathrm{m}^{2} \mathrm{~K}$. Both defects can be seen as plausible: the first defect is because of carelessness during construction while the second defect can occur when a window is old. All these simulations are also made with VIP-Energy.

\section{Results}

The energy calculations are isolated to include only the energy usage for heating connected to the specific apartment. This means that the figures cannot be compared with standard energy calculations for an entire building, which include hot water, residential electricity, heating of the stairwells and other common spaces etc. All figures in the following tables are based on a time period of six months, from $1^{\text {st }}$ of October to $31^{\text {st }}$ of March. 


\begin{tabular}{|l|l|l|l|l|}
\hline Supplied heat & \multicolumn{5}{l|}{} \\
\hline $\begin{array}{l}\text { Apartment/ } \\
\text { Occupancy }\end{array}$ & $\begin{array}{l}\text { Supplied energy } \\
\left(\mathrm{kWh} / \mathrm{m}^{2}\right)\end{array}$ & $\begin{array}{l}\text { Internal heat } \\
\text { production } \\
\left(\mathrm{kWh} / \mathrm{m}^{2}\right)\end{array}$ & $\begin{array}{l}\text { Body heat gain } \\
\left(\mathrm{kWh} / \mathrm{m}^{2}\right)\end{array}$ & $\begin{array}{l}\text { Solar radiation } \\
\left(\mathrm{kWh} / \mathrm{m}^{2}\right)\end{array}$ \\
\hline $\mathrm{A} 1 / \mathrm{A}$ & $60.3(+21 \%)$ & 14.4 & 3.3 & 1.2 \\
\hline $\mathrm{A} 1 / \mathrm{B}$ & 49.8 & 20.1 & 8.0 & 1.2 \\
\hline $\mathrm{A} 1 / \mathrm{C}$ & $34.5(-31 \%)$ & 28.8 & 14.9 & 1.2 \\
\hline $\mathrm{B} 1 / \mathrm{A}$ & $48.6(+27 \%)$ & 14.4 & 3.3 & 1.1 \\
\hline $\mathrm{B} 1 / \mathrm{B}$ & 38.2 & 20.1 & 8.0 & 1.1 \\
\hline $\mathrm{B} 1 / \mathrm{C}$ & $23.3(-39 \%)$ & 28.8 & 14.9 & 1.1 \\
\hline $\mathrm{Cl} / \mathrm{A}$ & $73.9(+17 \%)$ & 14.4 & 3.3 & 1.6 \\
\hline $\mathrm{C} 1 / \mathrm{B}$ & 63.4 & 20.1 & 8.0 & 1.6 \\
\hline $\mathrm{Cl} / \mathrm{C}$ & $47.9(-24 \%)$ & 28.8 & 14.9 & 1.6 \\
\hline
\end{tabular}

Table 3. The supplied heat for building 1, from 1st of October to 31 st of March.

\begin{tabular}{|l|l|l|l|l|}
\hline Supplied heat & $\begin{array}{l}\text { Supplied energy } \\
\left(\mathrm{kWh} / \mathrm{m}^{2}\right)\end{array}$ & $\begin{array}{l}\text { Internal heat } \\
\text { production } \\
\left(\mathrm{kWh} / \mathrm{m}^{2}\right)\end{array}$ & $\begin{array}{l}\text { Body heat gain } \\
\left(\mathrm{kWh} / \mathrm{m}^{2}\right)\end{array}$ & $\begin{array}{l}\text { Solar radiation } \\
\left(\mathrm{kWh} / \mathrm{m}^{2}\right)\end{array}$ \\
\hline Occupancy & $78.2(+15 \%)$ & 14.4 & 3.3 & 1.4 \\
\hline A2/B & 67.8 & 20.1 & 8.0 & 1.4 \\
\hline $\mathrm{A} 2 / \mathrm{C}$ & $52.3(-23 \%)$ & 28.8 & 14.9 & 1.4 \\
\hline B2/A & $61.2(+20 \%)$ & 14.4 & 3.3 & 1.3 \\
\hline B2/B & 50.8 & 20.1 & 8.0 & 1.3 \\
\hline B2/C & $35.6(-30 \%)$ & 28.8 & 14.9 & 1.3 \\
\hline C2/A & $104.6(+11 \%)$ & 14.4 & 3.3 & 1.8 \\
\hline C2/B & 94.1 & 20.1 & 8.0 & 1.8 \\
\hline C2/C & $78.5(-17) \%$ & 28.8 & 14.9 & 1.8 \\
\hline
\end{tabular}

Table 4. The supplied heat for building 2, from 1st of October to 31 st of March.

\section{1 Supplied heat}

Supplied heat includes the four categories: supplied energy, internal heat production, body heat gain and solar radiation. Supplied energy is the need for purchased/delivered energy. These four categories are presented in Tables 3 and 4, for Building 1 and Building 2 respectively.

Internal heat production, solar radiation and body heat gains have significance for energy supplied to all apartments. In apartment B1, the need for supplied energy increases by 27 per cent for occupancy A compared to occupancy B, and decreases by 39 per cent for occupancy $C$ (see Table 3). This high percentage difference in apartment $B 1$ is due only to its lesser need for supplied heat. With a larger need for supplied heat, as in apartment C2, the percentage difference is lower as there is an 11 per cent increase for occupancy A compared to occupancy B, and a 17 per cent decrease with occupancy $C$.

Solar radiation varies over the season and is most intense in the summertime when there is no need for heating. Between the first of October and the end of March in Sweden, solar radiation will not contribute much heat. However, it is possible to see a small difference in solar radiation depending on the orientation and whether the windows are dou- ble-glazed or triple-glazed. A larger difference can be seen with a large difference in window area.

\subsection{The apartment's location in the building}

There is a difference in energy use between the three apartments. Apartment $B$ in the middle of the building with surrounding neighbors has a favorable location because of the limited area of exterior walls and ceilings. For example, apartments A1 and $\mathrm{Cl}$ need 30 and 66 per cent more supplied energy respectively compared to apartment B1, with the normal occupancy B setting (see Table 5). In Building 2, which has a lower thermal insulation standard of the building envelope, a comparison between the three apartments will result in a small percentage increase. However, it can be misleading to look at the percentage difference alone. Although there is a 106 per cent difference in need for supplied energy between apartments B1 and $\mathrm{Cl}$; in the case of occupancy $\mathrm{C}$, the difference in absolute numbers is only $24.6 \mathrm{kWh} / \mathrm{m}^{2}$ or 1820 $\mathrm{kWh}$ (multiplied by $74 \mathrm{~m}^{2}$ ) for the whole heating season. The same comparison in Building 2 shows a $3175 \mathrm{kWh}$ difference (+121\%). 


\begin{tabular}{|l|l|l|l|l|l|l|}
\hline & \multicolumn{6}{|l|}{ Supplied energy $\left(\mathrm{kWh} / \mathrm{m}^{2}\right)$} \\
\hline Occupancy & $\begin{array}{l}\text { Apartment } \\
\text { A1 }\end{array}$ & $\begin{array}{l}\text { Apartment } \\
\text { B1 }\end{array}$ & $\begin{array}{l}\text { Apartment } \\
\text { C1 }\end{array}$ & $\begin{array}{l}\text { Apartment } \\
\text { A2 }\end{array}$ & $\begin{array}{l}\text { Apartment } \\
\text { B2 }\end{array}$ & $\begin{array}{l}\text { Apartment } \\
\text { C2 }\end{array}$ \\
\hline A & 60.3 & 48.6 & 73.9 & 78.2 & 61.2 & 104.6 \\
& $(+24 \%)$ & -- & $(+52 \%)$ & $(+28 \%)$ & - & $(+71 \%)$ \\
\hline B & 49.8 & 38.2 & 63.4 & 67.8 & 50.8 & 94.1 \\
& $(+30 \%)$ & -- & $(+66 \%)$ & $(+33 \%)$ & - & $(+85 \%)$ \\
\hline C & 34.5 & 23.3 & 47.9 & 52.3 & 35.6 & 78.5 \\
& $(+48 \%)$ & -- & $(+106 \%)$ & $(+47 \%)$ & - & $(+121 \%)$ \\
\hline
\end{tabular}

Table 5. The need for supplied energy depending on the apartments' location.

\subsection{Local defects in the building envelope}

The two local defects simulated in this study can both be seen as major defects. Despite this, the consequences in extra need for supplied energy can be perceived as quite small. The largest difference in need for supplied energy, 6.5 per cent, appears in apartment Bl where there is lack of insulation wool around some of the windows (see Table 6). Building 1 has a building envelope of fairly high thermal standard and a defect will therefore be more significant in Building 1 compared to Building 2, which had has less thermal insulation from the beginning.

\section{Discussion}

\subsection{Internal heat production and solar radiation}

The large amount of solar radiation and internal heat production will lower the need for supplied energy, which in this case means that the tenant has to pay less for heating the apartment. This is consistent with one of the basic thoughts concerning IMC: if someone uses less heat they should also pay less. However, internal heat production in combination with compensation for an apartment's less favorable location in a building can affect the accuracy of IMC, which will be explained later.

When the indoor temperature is measured, internal heat production significant affects the accuracy. Some of the internal heat production comes from electrical energy for which the tenant normally has to pay. At the same time, internal heat production lowers the need for supplied energy, which in this case will benefit the landlord or, in some cases, the energy company. This works in both ways. For example, occupancy A produces less internal heat compared to occupancy B and C. For the same indoor temperature, occupancy $A$ would actually require a higher heat supply than occupancy B or C. However, their costs will be the same and it is the landlord who has to stand the extra cost.

The difference in internal heat production between the two extreme occupancies in this study is, in total, $26.0 \mathrm{kWh} / \mathrm{m}^{2}$ or $1924 \mathrm{kWh}$ (multiplied by $74 \mathrm{~m}^{2}$ ) over the heating season. How much this is in relation to the need for supplied energy differs between the apartments. For example in apartment B1, the supplied energy decreases by 39 per cent for occupancy $C$ compared with occupancy B. In apartment $\mathrm{C} 2$, the supplied energy decreases by just 17 per cent for occupancy $C$ compared with occupancy B. This means that the percentage differences depend on the apartment's need for supplied energy, which in turn depends on the thermal standard of the building envelope together with the apartment's location in the building.

Another potential shortcoming with internal heat production is that it can temporarily raise the indoor temperature. This could mean higher heating costs, when in reality it should lower costs. If no temperature sensors are placed in rooms where the most internal heat is produced, as in the kitchen and the bathroom, this shortcoming can be mostly avoided. But not including the whole apartment can be perceived as incomplete measurements. Solar radiation can also temporarily raise the indoor temperature. However, this study does not reveal much influence from the sun during the six colder months in Sweden. It could be sensible to stop the measurements in the spring time well

\begin{tabular}{|l|l|l|l|l|l|l|}
\hline & \multicolumn{6}{|l}{ Supplied energy $\left(\mathrm{kWh} / \mathrm{m}^{2}\right.$, $)$ with Occupancy B } \\
\hline Type of Defect & $\begin{array}{l}\text { Apartment } \\
\text { A1 }\end{array}$ & $\begin{array}{l}\text { Apartment } \\
\text { B1 }\end{array}$ & $\begin{array}{l}\text { Apartment } \\
\text { C1 }\end{array}$ & $\begin{array}{l}\text { Apartment } \\
\text { A2 }\end{array}$ & $\begin{array}{l}\text { Apartment } \\
\text { B2 }\end{array}$ & $\begin{array}{l}\text { Apartment } \\
\text { C2 }\end{array}$ \\
\hline None & 49.8 & 38.2 & 63.4 & 67.8 & 50.8 & 94.1 \\
\hline $\begin{array}{l}\text { Lack of } \\
\text { insulation wool }\end{array}$ & 52.0 & 40.4 & 65.7 & 68.7 & 51.7 & 95.0 \\
$(+4.4 \%)$ & $(+5.8 \%)$ & $(3.6 \%)$ & $(+1.3 \%)$ & $(+1.8 \%)$ & $(+1.0 \%)$ \\
\hline $\begin{array}{l}\text { Defective } \\
\text { window frame }\end{array}$ & $\begin{array}{l}50.6 \\
(+1.6 \%)\end{array}$ & $\begin{array}{l}39.0 \\
(+2.1 \%)\end{array}$ & $\begin{array}{l}64.2 \\
(+1.3 \%)\end{array}$ & $\begin{array}{l}68.5 \\
(+1.0 \%)\end{array}$ & $\begin{array}{l}51.5 \\
(+1.4 \%)\end{array}$ & $\begin{array}{l}94.8 \\
(+0.7 \%)\end{array}$ \\
\hline
\end{tabular}

Table 6. Increase of supplied energy because of a local defect in the building envelope. 
before solar radiation begins to affect the indoor temperature too much.

\subsection{An apartment's location in the building}

The apartment's location in a building significantly affects its need for supplied energy. Between apartments B2 and C2 supplied energy differs by as much as 85 per cent. An interesting observation is that the percentage difference decreases in line with a higher thermal insulation standard for the building envelope. Between apartments $\mathrm{Bl}$ and $\mathrm{Cl}$ it differs by 66 per cent, a difference of 19 per cent compared to Building 2. In this study's most extreme case, for occupancy $C$, the difference between apartment $B$ and $C$ in Building 1 is 1820 $\mathrm{kWh}$ for the whole heating season, and in Building 2 the difference is $3175 \mathrm{kWh}$. This means that the issue of different heating needs, because of the apartment's location in the building, is of less significance in modern well-insulated buildings. In Denmark you have to compensate for an apartment's less favorable location when using IMC (Bygge- og Boligstyrelsen, 1996). In Sweden, this is mostly done when installing IMC in an existing building.

With a percentage discount, depending on the apartment's location, the measured amount of energy is reduced. A larger area of exterior walls and roof will be compensated by a higher percentage discount. The question is whether this truly represents reality?

The amount of internal heat production from the occupancies is a factor that could influence a percentage discount for an apartment's less favorable location in a building. This can be shown from a comparison between the two extreme occupancies $\mathrm{A}$ and $\mathrm{C}$. In apartment $\mathrm{Cl}$, which has a less favorable location, occupancy A needs 73.9 $\mathrm{kWh} / \mathrm{m}^{2}$ in supplied energy. At the same time occupancy $C$ needs just $47.9 \mathrm{kWh} / \mathrm{m}^{2}$ for the same apartment. The assumption that apartment $C$ is compensated with a 10 per cent discount for the less favorable location in the building, this will result in a discount for occupancy A of $547 \mathrm{kWh}(73.9 \mathrm{x}$ $\left.0.10 \times 74 \mathrm{~m}^{2}\right)$. For occupancy $C$ the discount will only be $354 \mathrm{kWh}$, a difference of $193 \mathrm{kWh}$.

Instead of a percentage discount there could be a fixed reduction based on a calculated increased amount of heat transmitted through exterior walls and ceilings. This would exclude all external influence on the discount such as the family size. Another option could be to not give any discount at all related to the apartment's location, as in Germany where the common standard is not to compensate for any unfavorable location. It is to be noted that Germany has a very different view on
IMC compared to Sweden due to various historical events (Siggelsten and Hansson, 2010). To compensate a gable apartment for its greater need for heat does not have to be a matter of course. It may well be the other way around.

\section{Local defects on the building envelope}

A potential shortcoming with measuring the supplied energy is a local defect in the building envelope. But its significance to the need of supplied energy is much less than the apartment's location in the building. The simulated defects in this study created a small increase in supplied energy, with a slightly higher percentage increase in the well-insulated Building 1 compared to Building 2 (see Table 6). In all three apartments in Building 1 the increased amount of supplied energy is $163 \mathrm{kWh}$ $(2.2 \times 74)$ due to lack of insulation wool. The main issue is that the tenant has to pay for the increased amount of energy needed because of any local defect, which really should be paid by the landlord. In addition, the landlord loses an economic incentive to repair the local defect or, even worse, to inspect the building envelope for any defects.

A local defect in the building envelope will only have a small impact of the need for supplied energy and should not affect the indoor temperature appreciably. However, the perceived (operative) temperature can be affected by downdraughts from defective windows or by cold radiation from surfaces with a poor thermal insulation standard. The effect of having a large difference between the measured indoor temperature and operative temperature should not be underestimated, especially if heat is charged by the indoor temperature.

\section{Conclusions}

It is important to emphasize that the results from this study may be different when other input data such as the climate and type of building are introduced. For example, the issue of different heating needs because of the apartment's location in the building was less significant in the modern well-insulated building.

The implication of these shortcomings is that it is very difficult to measure the actual heat used for an individual apartment. This makes is also difficult to apportion heating costs among tenants in a way equivalent to the actual energy used for heating. The investigated IMC methods affects, and are affected by, family size, the proportion of heating costs between tenant and landlord, and also between tenants. 
A large family contributes a larger amount of internal heat production compared with a small family, which in turn reduces the need for supplied energy. This means a lower heating cost for the large family if measuring the supplied heat. If instead the heat is charged by the indoor temperature, this results in a higher heating cost.

The location of an apartment in the building has a large influence on the apartment's heating demand. In this case the choice of IMC method affects apportionment of the heating costs among the tenants. When measuring the supplied energy, a tenant living for example on a gable apartment will have higher heating costs compared to living in an apartment located in the middle of the building. If instead the heat is charged by the indoor temperature the location of the apartment should normally not affect the heating costs. The exception of this is if the building envelope has a poor insulation standard which in turn will affect the operative temperature indoors.

Individual heat metering and charging is needed to involve the tenants and make them conscious of energy use and cost, with the possible result of reduced energy use in multi-apartment buildings. One way to reduce the significance of the shortcomings is to have a partly fixed and a partly variable cost for the heat. Having the heating costs as, for example, 50 per cent fixed and 50 per cent variable should in theory decrease the significance of this shortcoming by 50 per cent. How it will affect tenants' saving behavior is difficult to say, more research is needed in this matter. More research is also needed to develop a method for individual heat metering that is more accurate and less vulnerable to shortcomings.

\section{REFERENCES}

ANDERSSON, G. 2001, Kv Jankowitz - Individuell värmemätning och inverkan av värmeövergång mellan lägenheter, Bengt Dahlgren AB, Arbetsnummer: 50-8351101. Göteborg. (In Swedish)

BERNDTSSON, L. 2003, Individuell värmemätning i Svenska flerbostadshus - en lägesrapport, Swedish Energy Agency, Project nr. P1 1835-2, Eskilstuna. (In Swedish)

BOVERKET, 1999, Rekordåren - en epok i svenskt bostadsbyggande, The National Board of Housing, Building and Planning in Sweden, ISBN: 91-7147-568-0, Karlskrona. (In Swedish)

BOVERKET, 2006, Individuell mätning av värmeförbrukning i flerbostadshus i Tyskland - författningar, tekniker och erfarenheter, The National Board of Housing, Building and Planning in Sweden, ISBN: $91-7147-945-7$, Karlskrona. (In Swedish)

BOVERKET, 2009, Så mår våra hus - Redovisning av regeringsuppdrag beträffande byggnaders tekniska utformning m.m, The National Board of Housing, Building and Planning in Sweden, ISBN: 978-91-86342-29-6, Karlskrona. (In Swedish)

BYGGE- OG BOLIGSTYRELSEN, 1996, Bekendtgørelse om individuel måling af el, gas, vand og varme( ${ }^{*}$ 1), Kapitel 2 Individuel måling §9. (In Danish)

DIRECTIVE 2002/91/EC of the European Parliament and of the Council of 16 December 2002 on the energy performance of buildings. Official Journal of the European Communities, 4.1.2003.

ENERGIMYNDIGHETEN, 2007, Hushåll och energibeteende, Swedish Energy Agency, ISSN 1403-1892, Eskilstuna. (In Swedish)

ERIKSSON, B. 1993, Energisparpotentialer i bostadsbeståndet, Värmebalansmodell, ELIB Rapport nr 8. Statens institut för byggnadsforskning, Gävle. (In Swedish)

FANGER, P.O. 1997, Varme- og klimateknik Grundbog 2. Udgave - Kapitel 1 Indeklima, Danvak, Lyngby. (in Danish)

GAFSI, A., LEFEBVRE, G. 2003, Stolen heating or cooling energy evaluation in collective buildings using model inversion techniques, Energy and Buildings, Elsevier 35:3, 293-303.

SCHOU, P. 1982, Tillämpad experimentell beteendeanalys vid energisparande, Pedagogiska institutionen, Stockholm University, Stockholm. (In Swedish)

SCOTT, W.L. 1991, Energy conservation from individual heat use monitoring in multifamily properties, ASHRAE Winter Meeting - Technical Papers, Published by ASHRAE, Atlanta. 
SIGGELSTEN, S., HANSSON, B. 2010, Incentives for individval metering and charging, Journal of Facilities Management, Emerald, 8:4, 299-307.

SIGGELSTEN, S., OLANDER, S. 2013, Individual metering and charging of heat and hot water in Swedish housing cooperatives, Energy Policy, 61 (2013) 874-880.

STRUSOFT ${ }^{\circledR}$ (2010). VIP Energy Version 1.5.6. Copyright (C) Structural Design Software in Europe AB.

WANG, S. 2011. Technical Development of Chinese Heat Meters and market outlook, Unpublished Conference presentation at The First China Heat Metering Technology \& Management International Symposium \& Exhibition, Beijing.

Author(s):

\section{Simon Siggelsten}

Urban Studies, Malmö University

20506 Malmö, Sweden

Email: simon.siggelsten@mah.se

\section{Birgitta Nordquist,}

Building Service, Lund University

P.O. Box 118, 22100 Lund, Sweden.

Email: Birgitta.Nordquist@hvac.Ith.se

\section{Stefan Olander,}

Construction Management, Lund University P.O. Box 118, 22100 Lund, Sweden.

Email: Stefan.Olander@construction.lth.se 